\title{
Micropropagation of Turbinicarpus valdezianus (Möeller) Glass \& Foster (Cactaceae) an Endemic Cactus in Northern Mexico
}

\author{
Alejandro Martínez Palacios, Raúl Cárdenas Navarro', \\ and Diana Beatriz Hernández Ortega \\ Instituto de Investigaciones Agropecuarias y Forestales, UMSNH, Km 9.5 \\ carr. Morelia-Zinapecuaro, C.P. 58880, Tarímbaro, Michoacán, México
}

Víctor Chávez Avila

Jardín Botánico, Instituto de Biología, UNAM, circuito exterior, D.F. C.P. 04510, México

Additional index words. in vitro culture, shoot induction, 6-furfurylaminopurine, $\alpha$ naphthalenacetic acid

\begin{abstract}
An in vitro clonal propagation protocol based on axillary bud development was generated for Turbinicarpus valdezianus. An efficient multiplication rate was obtained using either longitudinal or apical explants from in vitro germinated seedlings. The proliferation capacity of these explants was evaluated by testing the single and interaction effects of five concentrations of 6-furfurylaminopurine (KIN) $(0.00,2.32$, 4.64, 9.28, and $18.56 \mu \mathrm{M})$ and three concentrations of $\alpha$-naphthalenacetic acid (NAA) $(0.00,0.54$, and $2.70 \mu \mathrm{M})$, using Murashige and Skoog (MS) as basal medium. Statistical analysis showed that the highest average shoot proliferation of $T$. valdezianus was recorded with $9.28 \mu \mathrm{M}$ of $\mathrm{KIN}$, producing 11.75 and 4.50 plantlets per initial explant, for apical and lateral explants, respectively. Addition of NAA to the medium had an inhibitory effect on shoot proliferation for both explant types. The developed shoots in $9.28 \mu \mathrm{M}$ of KIN and plant growth regulator (PGR)-free treatments were used for a rooting subculture phase. These shoots were then transferred to PGR-free MS medium, resulting in statistically significant different rooting frequencies of $78 \%$ and $97 \%$, respectively. When transplanted in soil, the rooted shoots showed an average survival rate of $90 \%$, without any significant statistical differences between treatments. This propagation protocol has the capacity to produce near to 21 plantlets per seedling in 27 weeks, i.e., 11.78 and 9.00 plantlets per apical and lateral explants, respectively, without callus or adventitious shoot formation. These features made it highly attractive as an in vitro clonal propagation method for $T$. valdezianus plants and the later implementation of a rescue program for threatened wild populations of this cacti species.
\end{abstract}

Turbinicarpus valdezianus (Möeller) Glass \& Foster (Cactaceae), endemic cactus from a very specific and narrow habitat in Northern México, is highly prized by collectors due to its peculiar morphology and attractive flowers (García-Osuna et al., 2011). This cacti species is listed under special protection SEMARNAT (2010) and was included in the CITES (2008) Appendix I, as a threatened species (CITES, 2008) by its very restricted geographic distribution. Moreover, its slow growth, low seedling survival rates, and the fragile condition of its habitat, make it susceptible to local extinction and, therefore, a good candidate for development of propagation protocols by

\footnotetext{
Received for publication 23 Oct. 2014. Accepted for publication 13 Nov. 2015.

This work was funded by the projects SEMARNAT-CONACyT 0350, CONACYT-SEP 47777, and CIC-UMSNH 5.6.

${ }^{1}$ Corresponding author. E-mail: rcardenasnavarro@ gmail.com.
}

tissue culture, which has proven to be a powerful and useful technique in the propagation of a large number of cactus plants, mainly in the genera Astrophytum, Aztekium, Cephalocereus, Cereus, Copiapoa, Coryphantha, Echinocactus, Echinocereus, Ferocactus, Gymnocalycium, Leuchtenbergia, Mammillaria, Nyctocereus, Opuntia, Rhipsalidopsis, Schlumbergera, and Stenocactus (Lema-Rumińska and Kulus, 2014). In the last few decades, several reports have been published about the plant micropropagation of the genus Turbinicarpus. Torres-Muñoz and Rodríguez-Garay (1996) achieved plant regeneration of Turbinicarpus pseudomacrochele through indirect somatic embryogenesis from medullar tissue disc cultured in MS basal medium supplemented with NAA and KIN, for induction of somatic embryogenesis and in the same basal medium solidified with phytagel for germination of somatic embryos. Mata-Rosas et al. (2001) obtained a large number of adventitious shoots from longitudinal sections of in vitro germinated seedlings of Turbinicarpus laui, cultured on MS basal medium supplemented with 6-benzylaminopurine (BA) with or without NAA; the adventitious shoots' development was preceded for abundant callus formation, which was augmented with the increase of BA concentration in the growth medium. These reports showed two techniques with high potential for in vitro multiplication of Turbinicarpus genus plants; however, their use is nonrecommended for conservation purpose because they may generate genetic variations (D'Amato, 1977; George 1993; Kartha, 1981; Lema-Ruminska and Kulus, 2014; MartínezPalacios et al., 2003). An alternative method to avoid this problem is the activation of axillary buds' development and then the rooting of shoots to generate plantlets (Lema-Ruminska and Kulus, 2014). This technique was applied in plants of eight threatened species of Turbinicarpus genus including $T$. valdezianus using apical, lateral, and transversal explants cultured on MS basal medium, supplemented with two cytokinins: BA or $6-(\gamma, \gamma$-dimethylallylamino $)$ purine (2iP). The results showed that, in most of the studied species, the transversal explants induced a higher number of shoots than the apical ones and that $T$. valdezianus showed the lower number of induced shoots in apical explants, mainly when BA was used; furthermore, callus development was reported in explants treated with this PGR (DávilaFigueroa et al., 2005). These results suggested that BA was not able to inhibit the apical dominance limiting the axillary buds development in apical explants and that this PGR involves the risk of somaclonal variation associated with callus development. Such results point out the necessity to explore the potential of other PGRs to induce the axillary bud development in stem explants of $T$. valdezianus plants. Because of the use of high or moderate concentrations of KIN with low concentration of NAA has been reported to be useful for this purpose in several species of Mammillaria genus (Lema-Ruminska and Kulus, 2014), the aims of this work were: a) evaluate the effect of several concentrations of KIN and NAA on the induction of axillary buds development from apical and lateral explants of $T$. valdezianus and b) determine the later effect of these PGR on in vitro rooting of induced shoots and establishment of plantlets in sterilized substrate in greenhouse.

\section{Materials and Methods}

Biological material. Seeds of T. valdezianus were collected in southeast Coahuila, Mexico. In the laboratory, visually healthy seeds (230) were selected and surface disinfected by rinsing for $1 \mathrm{~min}$ in $70 \%(\mathrm{v} / \mathrm{v})$ ethanol, followed by $20 \mathrm{~min}$ in $30 \%(\mathrm{v} / \mathrm{v})$ sodium hypochlorite (domestic bleach), and then washed three times $(30 \mathrm{~s}$ each) in sterile distilled water. Seeds (six per flask) were then aseptically transferred to glass flasks $(125 \mathrm{~mL})$ containing $30 \mathrm{~mL}$ MS salts (Murashige and Skoog, 1962). The flasks were maintained in a growth room at $27 \pm 1{ }^{\circ} \mathrm{C}$ temperature, 
$45 \mu \mathrm{mol} \cdot \mathrm{m}^{-2} \cdot \mathrm{s}^{-1}$ light intensity (provided by fluorescent lamps), and 16-h photoperiod.

Shoot development. After 20 weeks of incubation of cultured seeds in the growth room the obtained seedlings were removed, the roots were cut and the shoots were dissected in aseptic conditions, using a sterile scalpel, in two explant types: a) one apical explant ( $5 \mathrm{~mm}$ diameter and length) derived from a transversal cut of the apical section and b) two lateral explants $(10 \times 2.5 \mathrm{~mm})$ obtained from a longitudinal cut of the stem. Both explants type were used in a factorial experiment to evaluate the simple effect and the interaction effects of three concentrations $(0.00,0.54$, and $2.70 \mu \mathrm{M})$ of NAA and five concentrations $(0.00,2.32,4.64,9.28$, and $18.56 \mu \mathrm{M})$ of KIN in MS medium. The combinations of these factors generated 15 treatments, which were replicated 12 times; for each type of explant, one explant was cultured in each flask. The flasks were randomly distributed in a growth chamber under the conditions described above for seed germination, except that light intensity was increased to $60 \mu \mathrm{mol} \cdot \mathrm{m}^{-2} \cdot \mathrm{s}^{-1}$. Five weeks after the establishment, the shoot development was evaluated for both types of explants, considering only the shoots longer than $5 \mathrm{~mm}$.

Rooting. To evaluate the effect of PGR treatments of the shoot induction phase, on the in vitro rooting of shoots obtained from the best type of explant (apical or lateral shoot segments), a second experiment was established for comparing the rooting of shoots obtained from the best treatment containing PGR vs. the PGR-free treatment. These treatments were replicated five times in sterilized glass flasks $(125 \mathrm{~mL})$ containing PGR-free MS medium ( $30 \mathrm{~mL}$ ) with eight shoots per flask. The glass flasks were randomly distributed in the growth chamber under the same conditions described above for the shoot development experiment. Four weeks after establishment, root formation was evaluated considering the number of shoots with at least one visible root $(\approx 3 \mathrm{~mm})$.

Ex vitro plantlet establishment. Two weeks after the evaluation of root formation, the plantlets were established ex vitro to evaluate the effect of PGR treatment of explants at shoot induction phase on the survival of the plantlets. The treatments were the same used in the rooting experiment: best PGR treatment for shoot induction vs. PGR-free treatment (control). Plantlets $(n=40)$ of each group were washed during $1 \mathrm{~min}$ with running water and before immersed in $6 \%(\mathrm{w} / \mathrm{v})$ Agrimycin ${ }^{\circledR} 500$ (Pfizer Inc., New York, NY) for 3 min. Each group of plantlets was established in a germination tray $(20 \times 15 \times 5 \mathrm{~cm})$ containing noncommercial sterilized $\left(120^{\circ} \mathrm{C}\right.$ during $30 \mathrm{~min}$ ) substrate, composed of a mixture of sand, forest soil, and perlite (1:1:1) and placed in a greenhouse with a relative humidity of $70 \%$ to $90 \%$ and temperatures of $25-30{ }^{\circ} \mathrm{C}$. The plantlets were watered with distilled water twice a week until substrate saturation and during the first month were weekly sprayed with a solution of $6 \%(\mathrm{w} / \mathrm{v})$ Agri-mycin $^{\circledR} 500$. The survival rate of the plants was evaluated 16 weeks after establishment in the substrate.

Statistical analysis. The shoot development was analyzed using a two-way analysis of variance, and statistical differences were found when a Tukey's test was conducted. The rooting of shoots in vitro and the survival of plantlets ex vitro were analyzed independently using a $t$ test, assigning a value of 1 to individuals that developed roots and survived, and a value of 0 to those that did not. All statistics were carried out using the software SYSTAT ${ }^{\circledR} 11.1$ for Windows.

\section{Results}

Seed germination rate. Seed germination was $79 \%$ after 2 weeks, and after 20 weeks of culture, the plantlets reached an average size of $15 \mathrm{~mm}$ in height by $5 \mathrm{~mm}$ in diameter.

Effects of KIN and NAA on shoot development. Five weeks after establishment of the stem explants, the number of induced shoots was evaluated and noncallus development or hyperhydricity symptoms were observed in the induced shoots. In both explants types, the shoot proliferation showed statistically significant differences associated with the simple effect of KIN and NAA concentrations in the MS medium and to the interaction of both factors (Tables 1 and 2). In apical explants, the analysis of the simple effect of studied factors showed that the average number of induced shoots increased from 0.03 to 8.13 when the concentration of $\mathrm{KIN}$ in the MS medium enhanced from 0.00 to $9.28 \mu \mathrm{M}$ and that there is not statistically significant differences between the number of induced shoots in the treatments with 9.28 and $18.56 \mu \mathrm{M}$ of this PGR in the MS medium (Table 1). A contrariwise effect was registered for NAA, when its concentration in the MS medium increased from 0.00 to $0.54 \mu \mathrm{M}$ and to $2.70 \mu \mathrm{M}$, the average number of induced shoots per explant decreased from 5.88 to 4.02 and to 4.69 , respectively (Table 1). The interaction of both factors showed that the highest number of induced shoots was observed at $9.28 \mu \mathrm{M}$ of KIN in the growth medium, in the absence of NAA, with an average of 11.75 shoots per explant and that without PGR any induced shoot was registered (Table 1; Fig. 2A). In the lateral explants, the number of induced shoots was lower (general average of 1.63) than that of the apical segments (general average of 4.86); however, the simple effects of KIN and NAA concentrations generated similar patterns to those observed in the apical explants. In lateral explants, when KIN concentration increased from 0.00 to $9.28 \mu \mathrm{M}$ in the MS medium, the average number of induced shoots increased from 0.65 to 2.48 and there were no statistically significant differences between the number of induced shoots in the treatments with 9.28 and $18.56 \mu \mathrm{M}$ of this PGR in the MS medium (Table 2). The simple effect of NAA concentration on lateral explants was also similar to that observed in the apical segments. When this PGR was not added to the MS medium,
Table 1. Two-way analysis of variance of the effects of five concentrations of 6-furfurylaminopurine (KIN) and three concentrations of $\alpha$-naphthaleneacetic acid (NAA) in Murashige and Skoog medium on the shoot induction from apical explants of Turbinicarpus valdezianus stems.

\begin{tabular}{|c|c|c|}
\hline \multicolumn{2}{|c|}{ Source of variation } & Induced shoots \\
\hline \multicolumn{2}{|c|}{$\overline{[\mathrm{KIN}](\mu \mathrm{M})}$} & $P=0.000$ \\
\hline \multicolumn{2}{|l|}{0.00} & $0.03 \mathrm{c}$ \\
\hline \multicolumn{2}{|l|}{2.32} & $1.75 \mathrm{c}$ \\
\hline \multicolumn{2}{|l|}{4.64} & $5.39 \mathrm{~b}$ \\
\hline \multicolumn{2}{|l|}{9.28} & $8.13 \mathrm{a}$ \\
\hline \multicolumn{2}{|l|}{18.56} & $9.00 \mathrm{a}$ \\
\hline \multicolumn{2}{|l|}{ [NAA] $(\mu \mathrm{M})$} & $P=0.011$ \\
\hline \multicolumn{2}{|l|}{0.00} & $5.88 \mathrm{a}$ \\
\hline \multicolumn{2}{|l|}{0.54} & $4.02 \mathrm{~b}$ \\
\hline \multicolumn{2}{|l|}{2.70} & $4.69 \mathrm{ab}$ \\
\hline \multicolumn{2}{|c|}{$[\mathrm{KIN}](\mu \mathrm{M}) \times[\mathrm{NAA}](\mu \mathrm{M})$} & $P=0.000$ \\
\hline \multirow[t]{3}{*}{$0.00 \times$} & 0.00 & $0.00 \mathrm{e}$ \\
\hline & 0.54 & $0.09 \mathrm{e}$ \\
\hline & 2.70 & $0.00 \mathrm{e}$ \\
\hline \multirow[t]{3}{*}{$2.32 \times$} & 0.00 & $2.25 \mathrm{de}$ \\
\hline & 0.54 & $1.08 \mathrm{de}$ \\
\hline & 2.70 & $1.92 \mathrm{de}$ \\
\hline \multirow[t]{3}{*}{$4.64 \times$} & 0.00 & $5.08 \mathrm{~cd}$ \\
\hline & 0.54 & $4.67 \mathrm{cde}$ \\
\hline & 2.70 & $6.44 \mathrm{bcd}$ \\
\hline \multirow[t]{3}{*}{$9.28 \times$} & 0.00 & $11.75 \mathrm{a}$ \\
\hline & 0.54 & $8.00 \mathrm{abc}$ \\
\hline & 2.70 & 4.67 cde \\
\hline \multirow[t]{3}{*}{$18.56 \times$} & 0.00 & $10.33 \mathrm{ab}$ \\
\hline & 0.54 & $6.25 \mathrm{bcd}$ \\
\hline & 2.70 & $10.42 \mathrm{ab}$ \\
\hline
\end{tabular}

${ }^{\mathrm{z}}$ Different letters represent statistically significan differences according to Tukey's means paired test $(P<0.05)$.

an average of 2.8 induced shoots per explant was observed. This number was 0.65 and 1.41 when the NAA concentrations were raised to 0.54 and to $2.70 \mu \mathrm{M}$, respectively (Table 2). The interaction analysis showed that the treatment that showed the highest response in shoot production in lateral explants was similar to that was used for apical segments, i.e., 9.28 $\mu \mathrm{M} \mathrm{KIN}$ in the absence of NAA, with an average of 4.50 shoots per explant (Table 2). Furthermore, when both PGR were absent in the MS medium, an average of 1.95 induced shoots per explant was observed (Table 2).

Rooting. The first rooting response was registered on shoots induced in absence of KIN, 2 weeks after the shoots establishment in MS medium (results not shown). Four weeks after shoot establishment, significant differences between treatments were observed $(t=0.0074)$ : 97\% shoots induced in PGR-free media (control) showed root formation, whereas only $78 \%$ shoots obtained from $9.28 \mu \mathrm{M}$ of KIN (the best treatment for the shoots induction) presented root formation (Fig. 1A). The presence of KIN in the culture medium increased the in vitro shoot development of apical $T$. valdezianus explants; however, the obtained shoots delayed the emission of roots when they were cultured in PGR-free MS medium. The shoots were kept in this conditions two more weeks, at that moment, $98 \%$ of shoots grown in vitro showed roots in both treatments $(9.28 \mu \mathrm{M}$ of 
Table 2. Two-way analysis of variance of the effects of five concentrations of 6-furfurylaminopurine (KIN) and three concentrations of $\alpha$-naphthaleneacetic acid (NAA) in Murashige and Skoog medium on the shoot induction from lateral explants of Turbinicarpus valdezianus stems.

\begin{tabular}{ccc}
\hline Source of variation & Induced shoots \\
\hline [KIN] $(\mu \mathrm{M})$ & & $P=0.000$ \\
0.00 & & $0.65 \mathrm{c}^{\mathrm{z}}$ \\
2.32 & & $1.11 \mathrm{bc}$ \\
4.64 & $1.83 \mathrm{ab}$ \\
9.28 & $2.48 \mathrm{a}$ \\
18.56 & $2.08 \mathrm{ab}$ \\
& \\
[NAA] $(\mu \mathrm{M})$ & & $P=0.000$ \\
0.00 & & $2.84 \mathrm{a}$ \\
0.54 & $0.65 \mathrm{c}$ \\
2.70 & $1.41 \mathrm{~b}$ \\
& \\
[KIN] $(\mu \mathrm{M}) \times[\mathrm{NAA}](\mu \mathrm{M})$ & $P=0.000$ \\
$0.00 \times$ & 0.00 & $1.95 \mathrm{bcd}$ \\
& 0.54 & $0.00 \mathrm{~d}$ \\
$2.32 \times$ & 2.70 & $0.00 \mathrm{~d}$ \\
& 0.00 & $2.25 \mathrm{abcd}$ \\
$4.64 \times$ & 0.54 & $0.47 \mathrm{~d}$ \\
& 2.70 & $0.60 \mathrm{~d}$ \\
& 0.00 & $3.60 \mathrm{abc}$ \\
$9.28 \times$ & 0.54 & $1.15 \mathrm{~d}$ \\
& 2.70 & $0.75 \mathrm{~d}$ \\
$18.56 \times$ & 0.00 & $4.50 \mathrm{a}$ \\
& 0.54 & $1.25 \mathrm{~cd}$ \\
& 2.70 & $1.70 \mathrm{~cd}$ \\
& 0.00 & $1.88 \mathrm{bcd}$ \\
& 0.54 & $0.38 \mathrm{~d}$ \\
$\mathrm{Diffe}$ & 2.70 & $4.00 \mathrm{ab}$ \\
\hline
\end{tabular}

${ }^{\mathrm{z}}$ Different letters represent statistically significant differences according to Tukey's means paired test $(P<0.05)$.

KIN and control treatment) and their stems were $22.1 \pm 4 \mathrm{~mm}$ long and $4.5 \pm 0.7 \mathrm{~mm}$ wide, without statistical differences $(t=0.12$ and 0.34, respectively) (Fig. 2C).

Ex vitro plantlet establishment. The plantlets were established in soil after rooting evaluation (6 weeks after establishment in PGR-free MS medium). After 16 weeks of establishment in sterilized substrate in the greenhouse, there were no significant differences $(t=0.44)$ on the survival rates of plantlets generated from $9.28 \mu \mathrm{M}$ of KIN ( $87 \%$ survival rate) and the control treatment (93\% survival rate) (Fig. 2B); the average survival rate of plantlets in both treatments was $90 \%$ (Fig. 2D). After 16 weeks, plantlets were individually transplanted in plastic pots $(8 \times 8 \times 8 \mathrm{~cm})$ with the same substrate used in the survival phase for further development.

\section{Discussion}

Effects of KIN and NAA on shoot proliferation. It is well known that cytokinins induce the axillary buds development in the stem explants cultured in vitro, without or at low concentrations of auxins (George, 1993). This technique has been successfully used for commercial propagation of some threatened cacti species (LemaRuminska and Kulus, 2014). However, for the conservation purpose of endangered cactus, the in vitro multiplication is recommended through induction of axillary buds

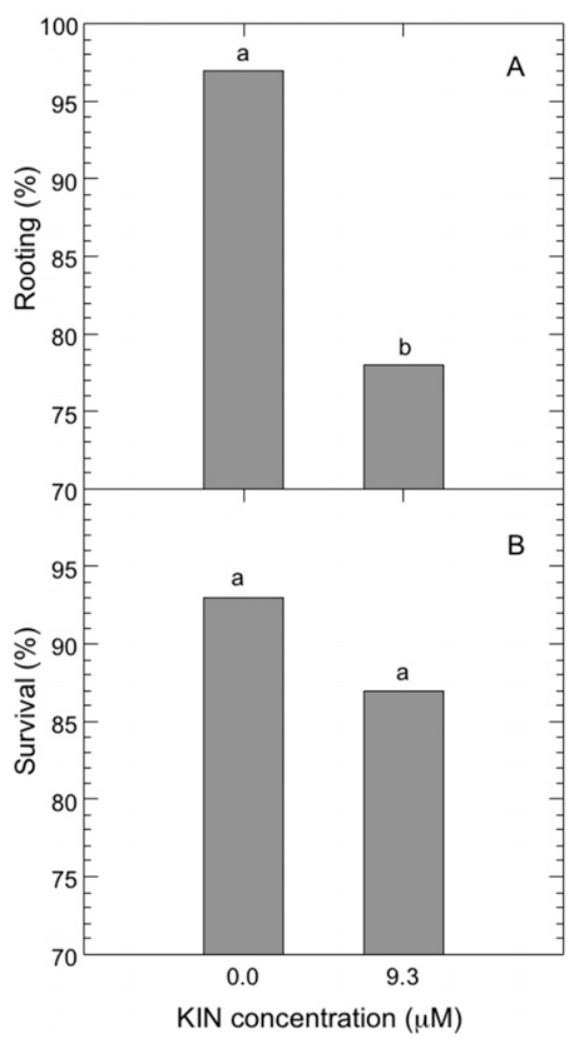

Fig. 1. (A) Roots formation in shoots induced from axillary buds of stem explants of Turbinicarpus valdezianus seedlings, after 4 weeks of in vitro cultivation in Murashige and Skoog (MS) medium without growth regulators and $(\mathbf{B})$ plantlets survival in soil after 16 weeks. In both cases, shoots used came from the shoot induction treatments with 0.00 and $9.28 \mu \mathrm{M}$ of 6-furfurylaminopurine (KIN) in the MS medium. Different letters represent statistically significant differences according to $t$ test $(P<0.05)$.

development, because other techniques involving callus development, induction of adventitious shoots, or somatic embryogenesis, could derivate in somaclonal variation (George, 1993). In cacti, a good way to stimulate the development of axillary buds in vitro is the use of high or moderate concentrations of cytokinins like BA or KIN and low or zero application of auxins (Lema-Ruminska and Kulus, 2014). The axillary buds development has been achieved using BA in the MS medium in the following endangered cacti species: Opuntia amyclaea (Escobar et al., 1986), epicotyl of Mediocactus coccineus (Infante, 1992), and apical stem segments of Agave victoriae-reginae (Martínez-Palacios et al., 2003); Pelecyphora aselliformis Ehrenberg and Pelecyphora strobiliformis Werdermann (Pérez-Molphe and Dávila-Figueroa, 2002); Echinocereus knippe-lianus, Echinocereus schmollii, Mammillaria carmenae, Mammillaria herrerae, Mammillaria theresae, Melocactus curvispinus, Escontria chiotilla, and Polaskia chichipe (Retes-Pruneda et al., 2007). The use of this PGR was also reported to induce the in vitro axillary buds development (in a second multiplication cycle) from stem explants laterals, transversals, and apicals of eight species of the genus Turbinicarpus, including $T$. valdezianus (Dávila-Figueroa et al., 2005). In this last study, the use of BA in $T$. valdezianus was not enough to breakdown the effect of the apical dominance, because apical explants presented only three induced shoots in the best treatment, while the best treatment in transversal ones showed until 7.8. In our work, the apical dominance of this cactus was also evident in apical explants cultured in absence of KIN, which did not show axillary bud development, but when KIN was added to the growth medium, apical dominance was inhibited and axillary bud development was induced. The highest number of shoots developed was 11.7 in apical explants cultured at $9.28 \mu \mathrm{M}$ of KIN in the absence of NAA. This value was higher than the sum of the highest number of induced shoots in both lateral explants (9) obtained from one seedling (Tables 1 and 2). Furthermore, Dávila-Figueroa et al. (2005) reported the occurrence of callus and the subsequent development of adventitious shoots in explants treated with BA, contrariwise in our work neither callus nor adventitious shoots were observed in explants treated with KIN. According to these results, $\mathrm{KIN}$ is more efficient than BA for the in vitro induction of axillary buds development of $T$. valdezianus. KIN induces a higher number of shoots, inhibits apical dominance, and excludes the development of callus and adventitious shoots; this last feature reduces the possibilities of somaclonal variation in obtained plants.

Rooting and ex vitro establishment. It is well established that rooting of shoots from cacti species, cultured in MS medium, may occur without addition of PGR (Ault and Blackmon, 1987; Fay and Gratton, 1992; MoebiusGoldammer et al., 2003; Rubluo et al., 1993; Smith et al., 1991), that the auxins accelerate root production (Escobar et al., 1986; Hubstenberger et al., 1992) and that the cytokinins inhibit the process (George, 1993; Stenlid, 1982). In the present study, in the shoot induction phase, the presence of KIN in the MS medium increased the shoot proliferation in apical and lateral explants in $T$. valdezianus; however, in the rooting phase, these shoots delayed the production of roots. The success of plantlet establishment in sterile substrate in greenhouse conditions was not modified by treatment with PGR in the shoot induction phase in this cacti species. The average plantlet survival of $90 \%$, observed in this work (Fig. 1B), is similar to previously reported results for Mammillaria san-angelensis (100\%) (Rubluo et al., 1993), T. laui (94\% to $100 \%$ ) (Mata-Rosas et al., 2001), Ariocarpus kotschoubeyanus (95\% to $100 \%$ ) (MoebiusGoldammer et al., 2003), and T. valdezianus (90\%) (Davila-Figueroa et al., 2005).

Considerations for conservation. The propagation system developed in the present work may generate 21 rooted plantlets per seedling in 27 weeks. It has great potential for cloning genotypes of threatened populations of $T$. valdezianus and can be used to alleviate illicit extraction of wild individuals from their 


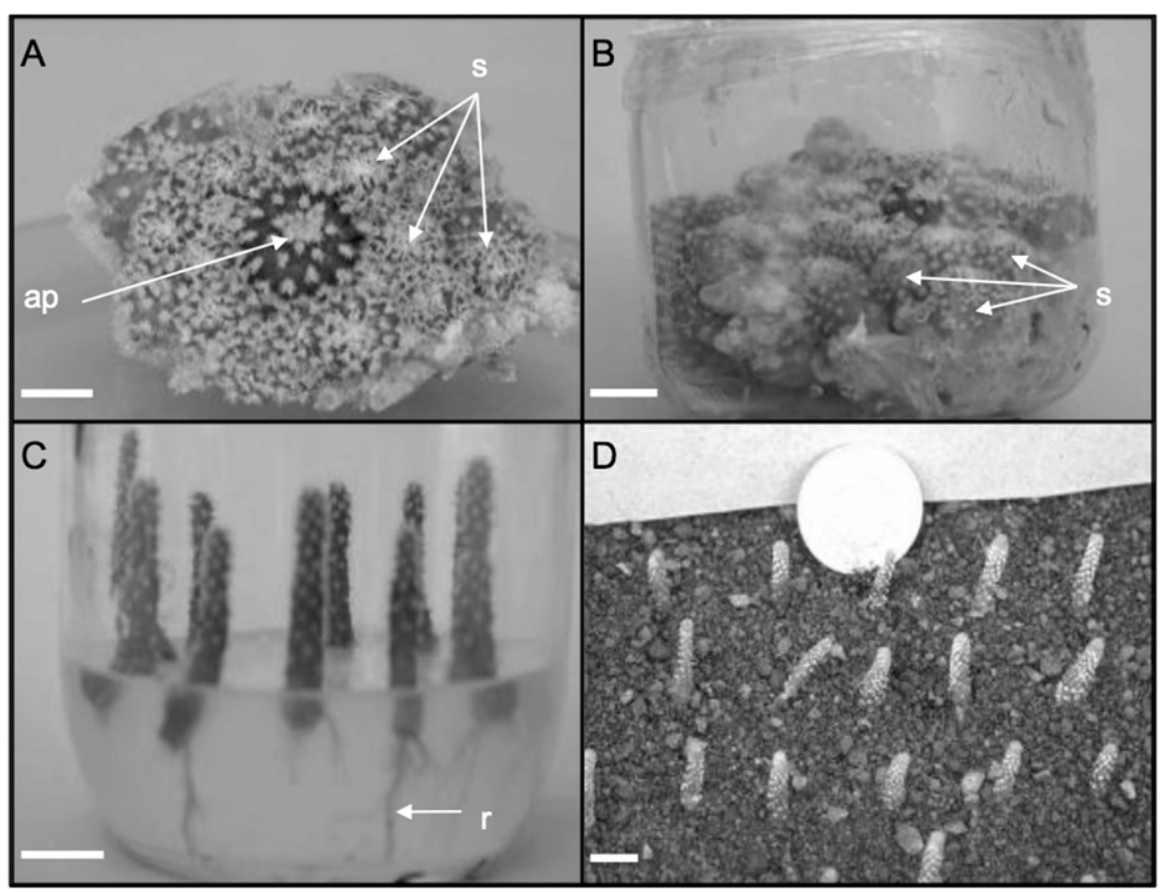

Fig. 2. Micropropagation of Turbinicarpus valdezianus. Apex with the development of multiple shoots (A); multiple shoots generated from stem segments (B); root formation in shoots cultivated in MS medium without growth regulators $(\mathbf{C})$; established in soil after 4 weeks of cultivation inside a greenhouse $(\mathbf{D})$; bar $=10 \mathrm{~mm}$; ap $=$ apex of the original explant; $\mathrm{s}=$ shoot; $\mathrm{r}=$ root.

natural habitat. The conservation of desired genotypes through small-scale clonal multiplication could be viable once a thorough study is conducted on the status of the wild population, following a similar procedure to the used in the case of Cercocarpus traskiae Eastw. (Rosaceae) in Santa Catalina Island, off of the coast of southern California: with only seven unique genotypes found in nature, it was decided to clone multiple of seven to prevent the extinction of any of them and let the environment generate evolutionary change of species (Mistretta, 1994). The knowledge generated by the present study has direct implications on the conservation of this and other endangered cacti species, particularly providing a culture system as a means to their passive and direct conservation.

\section{Literature Cited}

Ault, J.R. and W.J. Blackmon. 1987. In vitro propagation of Ferocactus acanthodes (Cactaceae). HortScience 22:126-127.

CITES. 2008. Appendices I, II, and III to the Convention on International Trade in Endangered Species of wild Fauna and Flora. U.S. Fish and Wildlife Service, Washington, DC. 15 Aug. 2015. <http://www.cites.org/esp/ app/appendices.shtml>.
D'Amato, F. 1977. Cytogenetics of differentiation in tissue cell cultures, p. 343-357. In: J. Reinert and Y.P.S. Bajaj (eds.). Applied and fundamental aspects of plant cell tissue organ culture. Springer-Verlag, Berlin, Germany.

Dávila-Figueroa, C.A., M.L. De La Rosa-Carrillo, and E. Pérez-Molphe-Balch. 2005. In vitro propagation of eight species or subspecies of Turbinicarpus (Cactaceae). In Vitro Cell. Dev. Biol. Plant 41(4):540-545.

Escobar, H.A., V.M. Villalobos, and A. Villegas. 1986. Opuntia micropropagation by axillary proliferation. Plant Cell Tiss. Org. Cult. 7:269277.

Fay, M.F. and J. Gratton. 1992. Tissue culture of cacti and other succulents: a literature review and a report on micropropagation at Kew. Bradleya 10:33-48. Escobedo-Bocardo, J.A. Villarreal-Quintanilla, and E. Cornejo-Oviedo. 2011. Hyperhydricity control of in vitro shoots of Turbinicarpus valdezianus (Moller) Gl. \& F. Phyton 80:175179.

George, E.F. 1993. Plant propagation by tissue culture. Vol. 1. The technology. Exegetics Ltd, England.

Hubstenberger, J.F., P.W. Clayton, and G.C. Phillips. 1992. Micropropagation of Cacti (Cactaceae), p. 49-68. In: Y.P.S. Bajaj (ed.). Biotechnology in agriculture and forestry. Springer-Verlag, Heidelberg, Germany.
García-Osuna, H.T., A. Benavides-Mendoza, L.
Infante, R. 1992. In vitro axillary shoot proliferation and somatic embryogenesis of yellow pitaya Mediocactus coccineus (Salm-Dyck). Plant Cell Tiss. Org. Cult. 31:155-159.

Kartha, K. 1981. Meristem culture and cryopreservation methods and applications, p. 181-211. In: T.A. Thorpe (ed.). Plant tissue culture methods and applications in agriculture. Academic Press, New York, NY.

Lema-Rumińska, J. and D. Kulus. 2014. Micropropagation of cacti-a review. Haseltonia 19:46-63.

Martínez-Palacios, A., P. Ortega-Larrocea, V. Chávez, and R. Bye. 2003. Somatic embryogenesis and organogenesis of Agave victoriaereginae: Considerations for its conservation. Plant Cell Tiss. Org. Cult. 74:135-142.

Mata-Rosas, M., M.A.R. Monroy, K.G. Moebius, and V.M.A. Chávez. 2001. Micropropagation of Turbinicarpus laui Glass et Foster, an endemic and endangered species. In Vitro Cell. Dev. Biol. 37:400-404.

Mistretta, O. 1994. Genetics of species reintroductions: Applications of genetic analysis. Biodivers. Conserv. 3:184-190.

Moebius-Goldammer, K.G., M. Mata-Rosas, and V.M. Chávez-Avila. 2003. Organogenesis and somatic embryogenesis in Ariocarpus kotschoubeyanus (Lem.) K. Schum. (Cactaceae), an endemic and endangered Mexican species. In Vitro Cell. Dev. Biol. Plant 39:388-393.

Murashige, T. and F. Skoog. 1962. A revised medium for rapid growth and bioassays with Tobacco tissue culture. Physiol. Plant. 15:473494.

Pérez-Molphe-Balch, E. and C.A. Dávila-Figueroa. 2002. In vitro propagation of Pelecyphora aselliformis Ehrenberg and $P$. strobiliformis Werdermann (Cactaceae). In Vitro Cell. Dev. Biol. Plant 38:73-78.

Retes-Pruneda, J.L., M.L. Valadez-Aguilar, M.E. Pérez-Reyes, and E. Pérez-Molphe-Balch. 2007. Propagación in vitro de especies de Echinocereus, Escontria, Mammillaria, Melocactus y Polaskia (Cactaceae). Bol. Soc. Bot. Méx. 81:9-16.

Rubluo, A., V. Chávez, A.P. Martínez, and O. Martínez-Vázquez. 1993. Strategies for the recovery of endangered orchids and cacti through in vitro culture. Biol. Conserv. 63:163-169.

SEMARNAT. 2010. Norma Oficial Mexican NOM-059-ECOL-2001. Protección ambiental. Especies nativas de México de flora y fauna silvestres. Categorías de riesgo y especificaciones para su inclusión, exclusión o cambio. Lista de especies en riesgo. Diario Oficial de la Federación, 30 de Diciembre de 2010.

Smith, R.H., P.J. Burdick, J. Anthony, and A. Reilley. 1991. In vitro propagation of Coryphantha macromeris. HortScience 26:315.

Stenlid, G. 1982. Cytokinins as inhibitors of root growth. Physiol. Plant. 56:500-506.

Torres-Muñoz, L. and B. Rodríguez-Garay. 1996. Somatic embryogenesis in the threatened cactus Turbinicarpus pseudomacrochele (Buxbaum and Backerberg). J. Prof. Assoc. Cactus Dev. $1: 36-38$. 